\title{
外転ギプス法で治療したペルテス病の予後調査
}

長 崎大学整形外科

松 本 智子・岩 崎 勝 郎
山田健 二

北九州市立八幡病院整形外科

片山修史

\section{Follow-up Study of Perthes' Disease Treated by the Abduction Weight Bearing Method}

\author{
by \\ T. Matsumoto, K. Iwasaki, K. Yamada \\ Department of Orthopaedic Surgery Nagasaki University, \\ School of Medicine \\ S. Katayama \\ Department of Orthopaedic Surgery Kitakyushu City \\ Yahata Hospital
}

\begin{abstract}
The purpose of this study is to discuss the advantage of the abduction weight bearing treatment. Thirty-one patients with Perthes' disease treated by this method were evaluated at an average follow-up of ten years after onset. They were classified into four groups according to Catterall's method in the order of increasing severity of involvement of the femoral epiphysis. In each group the results were evaluated ragiologically. As the degree of epiphyseal involvement became severe, the result became worse. On the other hand, for less than six years old the results were good except for the cases of group 4. Although this method could not obtain good results in the case of group 3 and 4 because of the coxa magna, short neck and overgrowth of the greater trochanter, the articular surface of the femoral head was kept smooth and spherical. We believe this fact is an advantage of the abduction weight bearing treatment.
\end{abstract}

\section{はじめに}

ペルテス病に対する治療成績は, 現在までに数多く 報告されているが, ペルテス病の予後には, いろいろ な因子が影響を与えているため，それらを抜きにして 単に治療成績だけを比較することは，あまり意味をな さないと思われる. 我々の教室でも 1974 年に岩崎 ${ }^{2}$ らが外転ギプス法で治療したペルテス病を中心にその 治療成績を発表したが，その時は，予後に最も大きな 役わりを演ずるとされる，骨頭障害の程度を考慮して いないものであった. 今回は, 前回報告した外転ギプ ス法の症例に対し, 再度, 予後調查を行ない, これら
を Catterall1) の提案した方法に従い，骨頭障害の程 度をグループ 1 から 4 まで分類し，そのグループ別に 治療成績を判定した. その結果を報告するとともに， 外転ギプス法の意義を中心に若干の考察を加えたい.

\section{対}

象

外転ギプス法で治療をうけたペルテス病の患者は 52 例 54 関節であったが, 今回, 直接検診し得た 31 例 を調査の対象とした．これらの follow up 期間は 6 $\sim 13$ 年 (平均 10 年), ギプスの装着期間は, 平均 1 年 7 か月であった. 我々の行った外転ギプス法は，2 か ら 3 週間の牽引で拘縮を除去した後, 大腿中央より足 
先までギプスを巻き，両股関節が約 45 度外転位をと るように両下肢に木製のバーをとりつけたあのであ る. ギプス装着中は，乙の状態で，起立，歩行などあ らゆる行動を許可した.

\section{治療成績の評洒法}

骨頭，および，epiphysis の形を客観的に評価する ために, Meyer ${ }^{6)}$ の提唱した, Joint-surface Quotient (J.S.Q.) および Epiphyseal Quotient (E. Q.）を用いた. J.S.Q.は，大腿骨骨頭を球の一部之 考え, その関節面は, 球の表面積内のどれくらいを占 めているかを，健側との比をとって表わしたものであ る. 即ち，值が 100 に近ければ，それだけ正常に近い わけである. Meyer は，85\%以上を正常範囲として おり，我々もそれにならった。

Epiphyseal Quotient (E. Q.) は Epiphysis の 扁平化の程度を表わす指標である. Mose は E. Q. が $60 \%$ 以上であれば，正常か正常に近い骨頭の形を しているとし，我々あそれにならい60\% 以上を正常 範囲と考えた.

また，大転子高位の程度を表わすために, Articulo Trochanteric Distance (A. T. D.) を測定した.

そして, X 線学的な総合評価法としては Catterall の方法にならって, 骨頭の形, および, その cover の状態を参考にして, good, fair, poor, の 3 段階 に, わけた.

\section{結 果}

（1）グループ別にみた J. S. Q.

図 1 亿示すように, 骨頭障害の程度が強いほど, J. S. Q. の值む小さくなって， $85 \%$ 以上を示すすの は, グループ 1, 2 では, $83 \%$ \%あのに, グループ 3,4 では $46 \%$ かない.

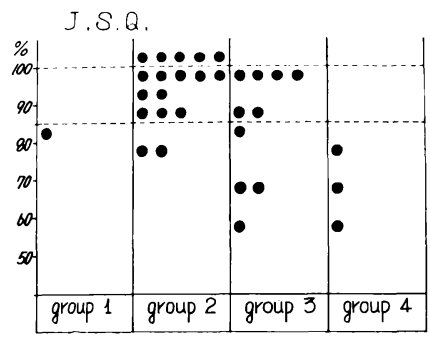

図 1
（2）グループ別にみた E. Q.

図 2 に示すように, 骨頭障害の程度が強いほど, E. Q. の值も小さくなって $60 \%$ 以上を示すものは,

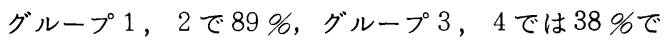
ある.

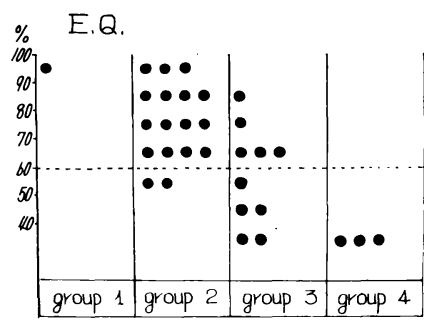

図 2

（3）グループ別にみた A. T. D.

図 3 に示すごとく，グループ 4 では著明な大転子高 位を示す例が大部分であったが，グループ 2 と 3 で ではかなりのバラッキがみられた．更に A. T. D. と, 頸部の囊腫様陰影との関係を論べてみると, この 陰影を合併しているものは，大転子高位が著明なよう にも思えるがこの点に関しては，もう少し症例を增や して検討したい.

A.T.D.

\begin{tabular}{|c|c|c|c|c|}
\hline 20以上 〜 & & $0^{*}$ & & \\
\hline 15以 20 & & - & 80 & $x^{x}$ \\
\hline 10以上 $\sim 15$ & & $\bullet \bullet$ & $0^{x} \bullet \bullet$ & $0^{x}$ \\
\hline 5以上 $\sim 10$ & & *e & $\bullet \bullet$ & \\
\hline 0 5末渾 & $\bullet$ & $\begin{array}{llll}* & \bullet & \bullet & \bullet \\
\bullet \bullet & \bullet & \bullet & 0\end{array}$ & $\bullet \bullet$ & \\
\hline & group 1 & group 2 & group 3 & group 4 \\
\hline
\end{tabular}

図 3

（4）グループ別にみた総合評価

図 4 に示すごとく, 骨頭障害の程度が強いほどその 結果も悪くなっており, 特に, グループ 4 では, 症例 数は少ないが全例 poor であった.

以上の結果より, 全体的にみて, 骨頭障害の程度が 強いほど，治療成績も悪いことがわかったが，同じ治 療が行なわれたにあかかわらず，同一グループ内にお いても結果に差がみられ，更に治療開始時の年令や stage について調べてみた. 


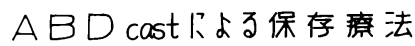

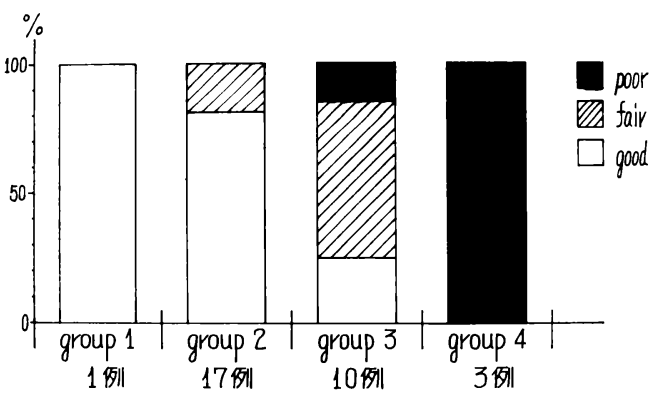

図4外転ギプス（ABD Cast）に よる保存療法の総合評価

（5）治療開始時の年令と予後との関係

図 5 に示すごとく，年令が若いほど治療成績は良 く, 特に 6 才以下では,グループ 2,3 においては全 例 good であった. しかし，グループ4では，年令 に関係なく，全例， poor であることがわかった.

また，男女差については，症例数が少なく特にその 差は,はっきりしなかった。

年令との阅係

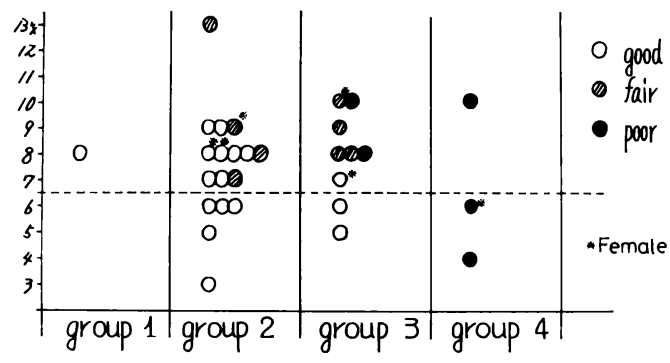

図 5

Stage at the Beginning of Treatment

Synovitis Stage Fragmentation Stage

\begin{tabular}{|c|c|c|c|}
\hline & Good & Fair & Poor \\
\hline Group 1 & $\mathrm{O}$ & & \\
\hline Group 2 & $\begin{array}{l}0000 \\
0000000 \\
0\end{array}$ & $\begin{array}{l}00 \\
00\end{array}$ & \\
\hline Group 3 & 0 & 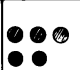 & 10 \\
\hline Group 4 & & & $\begin{array}{l}0 \\
00\end{array}$ \\
\hline
\end{tabular}

図 6
（6）治療開始時の stage と予後との関係

図 6 に示すでとく，本シリーズでは，治療開始時の stage と，その結果には，特に関連性はみられず，た とえ早期から治療を始めてもグループ4のように，骨 頭障害の程度が強ければ予後も悪かった。

\section{考察}

外転ギプス法の有用性について Katz'（1975）は， ペルテス病の予後には亜脱臼が大きな影響を与えてお り，外転位にすることにより，亜脱臼を防止できると し，また Kamhi (1975) は，異常なストレスに対す る機械的な変化は本症の初期におこり，乙の時期に ace tabulum で骨頭を充分におおえれ゙，変形を防ぐこ とができると言っている，ただし，彼らは外転位でし かも免荷を条件としているが, Somerville ${ }^{8)}$ (1971) やPetrie ${ }^{7)}$ (1971) は，骨頭を外転位で，acetabulum の深部におくことにより, acetabulum の外 縁があたるのを防ぎ，また，軟骨面に均等に圧がかか ることにより，正常な形の骨頭に発達させることがで きるとし，免荷は必要でなく，外転位で，しかも，荷 重を許可している，我々も彼らと同様な考えに基づ き，外転位に保持した状態で荷重を許可した。 ての， 治療成績をみると，骨頭障害の程度の軽い，グループ 1，2では，良好な結果を得ているが骨頭障害の程度 の強いグループ 3，4では，必ずしあ良好な解剖学的 治癒は得られず，外転ギプス法によっても，骨頭の巨 大化，扁平化を完全に防止するてとは困難であった。 また，同一グループ内においても結果に差があり，一 般に，治療開始時の年令が 6 才以下のあのは予後が良 かった.しかし，グループ 4 では年令に関係なく予後 不良であった．乙れら，骨頭障害の程度や治療開始時 の年令が，予後に大きく関与していることは，Catterall' や， Kamhi ${ }^{31}$ らを始めとし，多くの報告があ る. Kamhi は, グループ1や 6 才未満のグループ 2 では治療法とは関係なく結果は良好で，6才以上のグ ループ2，および，グループ $3 ， 4$ では， containment therapy をした方が，結果は良かったとしてい る. また Catterall は,グループ 1 および，4才以下 のグループ 2 では，治療法とは関係なく良好な結果を 示したが，4才をこえた年長児のグループ 2 では治療 の効果があったとしている．しかし，グループ $3 ， 4$ に対しては，保存的療法による効果はなかったとして いる. また，最近，Kelly5) は, containment ther- 
apy 以外の方法で保存的に治療したペルテス病の患 者について，予後調查を行ない，Catterall のグルー プ1，2では全員 good であったが，グループ 3， 4では poor から fair の結果を示すあのがあり，そ のうち, fair は, すべて6才以上であり, poor は, すべて8才以上であったとしている，その結果，彼 は,グループ1，2 亿対しては containment therapy は必要でなく，グループ 3，4亿対してのみ containment therapy が必要であると言っている.

以上，文献的報告と，我々の結果とを考えあわせる と, ペルテス病の治療にあたり, 骨頭障害の程度と, 治療開始時の年令とを，考慮することが大切であると とがわかる. そして，グループ1，2 で，しかも， 6 才以下であれば, 特に containment therapy の必 要はなく，良好な結果が予想される，一方，グループ 3，4 および 6 才をこえる年長児においては，containment therapy が有効であったとする報告は多く みられるものの, good と判定されているものは, Kamhi らの報告では $14 \%$, Catterall の, 報告では $20 \%$ あり，また，本シリーズでも good は $23 \%$ 之, 大体, 同様の結果であって, containment therapy でグループ 3，4 を満足すべき骨頭の形態に治㾤

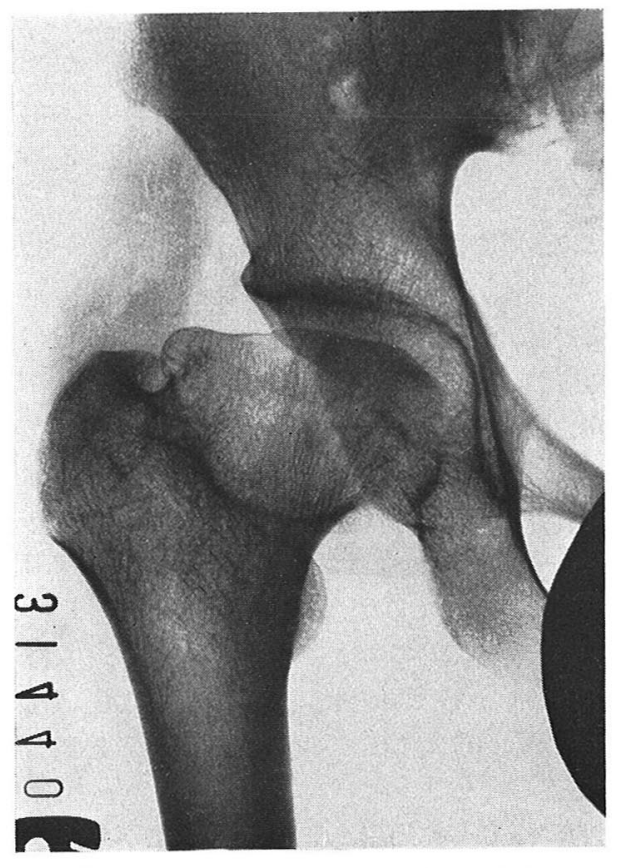

図7ペルテス病放置例 21 才男性
せしめるには程遠いと，言わなればならない，しか し，むっとも，不満足な症例でも，図 7 に示す放置例 にみられるような，高度の骨頭の irregularity を示 した例はなく，骨頭関節面は，一応の平滑さが保たれ ており，乙の点が，外転ギプス法の最大の利点である と考えている.

以上のようなととから，外転ギプス法の利点を，ぺ ルテス病の治療にどうとりいれていくかというととが 重要であると思われるが，それには，まず，個々の症 例の重症度を判定せ称ばならない，とてろが X線上 で, Catterall の分類が可能となるには, 発症後 8 か 月は，必要なのである，Kelly5) は，骨シンチにより， Catterall の分類が早期に可能であったとしている が，乙れは必ずしも一般的な方法とは言いがたい，そ れで，6才未満の未就学児は，外来通院などで，その 重症度が判定できるまで経過をみて，グループ 3，4 であれば， Containment therapy を確実にするた めに内反骨切り術を，また，6才以上の場合には，就 学の問題むあって，早期に内反骨切り術を行い，骨瘁 合が完成すれば，荷重歩行により，通学を許可してい るのが現状である.

結語

(1)外転ギプス法で治療したペルテス病の患者 31 人 について予後調查を行った.

(2)骨頭障害の程度を Catterall の方法に従って，グ ループ 1 から 4 まで分類し，そのグループ別に治療成 績を評価した。

(3)骨頭障害の程度が強い程，治療成績は悪かった。

(4)一般に6才以下では予後が良かったが，グループ 4 では年令に関係なく予後は悪かった.

(5)外転ギプス 法により骨頭の極度の irregularity を，ある程度，防止することができた。

\section{文献}

1) Catterall, A.: J. Bone and Joint Surg., 53-B, 37-53, 1971.

2) 岩崎勝郎 - 他：臨朱整形外科，9，368-376, 1974.

3) Kamhi, E. et al.: J. Bone and Joint Surg., 57-A, 651-654, 1975.

4) Katz, J. F. et al.: Clin. Orthop., 106, 7585,1975

5) Kelly, F. B. et al.: J. Bone and Joint Surg., 62-A, 400-407, 1980. 
6) Meyer, J.: Acta Orthop. Scand. suppl., No. 86, 1966.

7) Petrie, J.: J. Bone and Joint Surg., 53-B, 54-62, 1971.

8) Somerville, E. W.: J. Bone and Joint Surg., 53-B, 639-649, 1971.

質 問 久留米大学整形 奥 野 徹子 私達はペルテス病に対して外転免荷装具を使用して いますが，成績を調べてみますとCatterall の group 4 であ発症年令が 4 才の例では good の症例があり, この点が A-Cast では group 4 ではすべて poor であったということと異なっているような印象を受け ました。

\section{回答長崎大学 松 本 智子}

改奥野先生に対して

カテラールの group 4 に属した症例は, 3 例しか なく，その内では年令に関係なく全例 poor であっ た. 症例数が多ければその中には, poor でないもの ああったかもしれないが，何とも言えない，ただ，奥 野先生らの方法が group 4 にも効果があったという 結果には注目したい.

乞内反骨切り術に対しては，経過がまだ短いので，い ずれあらためて，その結果は，報告したい.

\section{発言九大西尾篤人}

ペルテス病の保存的治療法として外転免荷装具療法 を行っている. 大腿骨頸部の変化の強いものでは成長
軟骨への障害をも最小によどめるためにも免荷は必要 と考えている．治療開始時の骨頭の変形が予後を大き く左右する. 年長児の Catterall の group 4 でも丁 寧に治療すればよい結果を得ており，転子部の内反骨 切り術も有用ではあるが変形が発生していなければ保 存的の方がよい.

\section{翼 問琉大 茨木邦夫}

Group IV の例の abduction brace を行った例 と, Osteotomy を行った例との間に明らかな差があ りましたら教えて下さい。

\section{発 言長崎大学 岩 崎 勝 郎}

(1)ペルテス病における免荷について

外転ギプスを装着後荷重を許可した例の結果が，今 回のデーターとなってでているが，Catterall の分類 による group 4 は good はなかった. これは荷重許 可によものか，ある程度運命づけられたものかが問題 となるが，乙のような例における免荷の必要性につい ては，あう少し症例をふやして検討したいが，実際 上，学童児に長期間免荷を強いることが困難なととは 事実である.

(2)内反骨切り術について

外転ギプス法の経験から head containmet therapy では骨頭関節面の irregularity は防ぐことがで きるとの考え方から，骨切り術を行なっているが，結 果は別の機会に報告したい. 